кандидат юридических наук, юрисконсульт ООО «Балтторг»

\section{К ВОПРОСУ О ПРОДАЖЕ ТЕРРИТОРИИ ГОСУДАРСТВА В МЕЖДУНАРОДНОМ ПРАВЕ}

\begin{abstract}
Аннотация:
В статье анализируется допустимость куплипродажи государственной территории с точки зрения международного права. Даются исторические примеры отдельных сделок. Обосновывается актуальность данного вопроса в настоящее время. В результате делается вывод о том, что купля-продажа государственной территории возможна только при соблюдении определенных условий: проведение сделки на добровольных началах, подтверждение решения итогами референдума, ратификация международного договора, лежащего в основе сделки и т. д. Кроме того, не должно нарушаться право граждан на выбор принадлежности к тому или иному государству, поскольку приобретается территория, а не население. Однако автор статьи подчеркивает, что сделанные выводы имеют значение только для государств, в законодательстве которых отсутствует запрет на отчуждение территорий.
\end{abstract}

Ключевые слова:

государство, территория, суверенитет, территориальная целостность, государственные границы, цессия, население, гражданство.
PhD in Law, Legal Counsel, Balttorg, LLC (Russia)

\section{TOWARDS THE ISSUE OF SELLING STATE TERRITORY IN INTERNATIONAL LAW}

Keywords: state, territory, sovereignty, territorial integrity, state borders, cession, population, citizenship.

Изменение государственных границ в результате сделок купли-продажи территории в последнее время является актуальным вопросом для исследования в силу, например, подобных планов Греции из-за большого количества долгов. В то же время поправка 2020 г. к Конституции России требует защиты суверенитета и территориальной целостности государства, запрещая действия, направленные на отчуждение части территории, а также призывы к таким действиям (ч. 2.1, ст. 67).

Целью данного исследования является рассмотрение допустимости продажи территории государства с точки зрения международного права. Значимость работы повышает тот фракт, что в российской науке почти нет работ, посвященных современному состоянию проблемы.

Один из правомерных способов приобретения государственной территории в международном праве - продажа территории, разновидность возмездной цессии [1, с. 210]. Такое правовое основание предполагает добровольную передачу части территории государствами друг другу [2, с. 1260]. Насильственное изменение территории государства является нарушением Устава ООН и в современном международном праве запрещено. При этом территории могут передаваться не только по результатам «военных» конфреренций (например, включение территории бывшего Кенигсберга Восточной Пруссии после 1945 г. в состав СССР и трансформация региона в эксклав РФ [3, с. 20]). В качестве примера можно привести приобретение Россией по итогам Ништадтского мира в XVIII в. Прибалтики, в 1947 г. СССР купил у Финляндии территорию площадью 176 кв. км за 700 млн фринских марок.

В истории Соединенных Штатов Америки также есть примеры, когда некоторые территории были куплены у других государств. Все началось с покупки голландцами у индейского вождя территории острова Манхэттен (современный Нью-Йорк) за 60 гульденов (24 долл.). В 1867 г. в царствование Александра II была продана экономически убыточная на тот момент Аляска за 7,2 млн долл. (около 2 центов за акр земли). США приобрели у Дании в 1916 г. за 25 млн долл. Виргинские и Антильские острова. У Франции в 1803 г. были куплены Луизиана с Новым Орлеаном и его окрестностями за 600 млн французских франков, территория Флориды у Испании в 1819 г. и территории Калифорнии и Нью-Мексико у Мексики в 1848 г. за 18 млн 250 тыс. долл. [4]. Во время 
постройки Панамского канала США купили острова в Тихом океане, в 1928 г. приобрели острова у Никарагуа и Колумбии, в 1940 г. - территории восьми военно-морских баз у Великобритании.

В последнее десятилетие вопрос продажи территории другому государству вновь актуализировался в контексте фринансового кризиса в Греции. В 2012 г. тогдашний премьер-министр Греции А. Самарас сделал заявление, что отдельные греческие острова могут быть проданы, хотя в свое время спор из-за острова Имия между Грецией и Турцией сопровождался военными маневрами.

Также в качестве примера можно привести состоявшуюся в 2014 г. покупку государством Кирибати из-за угрозы повышения уровня моря 5,5 тыс. акров земли на Фиджи за 9 млн долл. При этом кирибатцы при переезде на данную территорию становятся жителями Фиджи, что свидетельствует о недоработанности вопроса статуса населения.

В 2019 г. президент США Д. Трамп сделал предложение о покупке территории Гренландии (самоуправляемого датского острова). Здесь можно вспомнить, что США едва не купили Гренландию и Исландию в 1860-е гг. Юридически обосновать данное предложение можно было бы концепцией Дж. Блохера и М. Гулати, профессоров Юридической школы Университета Дьюка в Северной Каролине. Данная концепция, обнародованная в 2017 г. в поддержку создания рынка суверенных территорий [5], вызвала бурную дискуссию. Значительным недостатком представляется то, что в условиях высокого уровня развития избирательных технологий самостоятельному отдельному волеизъявлению народа доверять нельзя. Безусловно, возникнут вопросы, связанные со стоимостью территорий: каким образом определить справедливость и объективность ее оценки? Кроме того, возникнет угроза, что богатые нации будут скупать территории у бедных. Представляется, что компенсация за продажу территории может принимать не только денежную форму, но и военные или политические обязательства государств друг перед другом [6, с. 24].

Передача территории представляется допустимой, если государство не в состоянии обеспечить должное развитие инфраструктуры. Это может оказаться полезным для государств, в которых отсутствует «надлежащее управление», и подобные сделки приведут к улучшению качества жизни населения [7]. Также значительную выгоду подобная сделка могла бы принести государствам, не имеющим выхода к морю, например, Боливии, нуждающейся в доступе к морю через Чили, или Ботсване, нуждающейся в выходе к морю через Намибию.

Однако возникает вопрос: не вернется ли тем самым мировое сообщество в колониальную эпоху? Не вызовет ли это злоупотреблений сложным финансовым положением государства-продавца и его граждан? Ведь предоставление жителям приобретенных территорий гражданства страны-покупателя не обязательно положительно влияет на судьбу населения. Например, жители Пуэрто-Рико являются гражданами Соединенных Штатов, однако их уровень жизни значительно ниже.

В международном праве нет четких норм, регулирующих осуществление купли-продажи государственной территории. Такие сделки затрагивают интересы проживающего на территории населения. Следовательно, для проведения легитимных сделок цессии как правового способа изменения государственной территории необходимы гарантии недопущения злоупотреблений, соблюдения принципов самоопределения наций и народностей. Поэтому крайне важным представляется добровольное согласие на сделку государств [8].

В современном праве действует принцип территориальной целостности государств, нерушимости государственных границ как юридический механизм защиты интересов государства. Из этого принципа следует обязанность государств не признавать сделок, нарушающих этот принцип [9, с. 59].

Еще одна гарантия состоит в том, что продажа относится к договорным способам приобретения государственной территории, которая передается на основании международного публичного договора [10, с. 8]. Этот договор является правовой основой сделки. Как правило, дата перехода титула - дата вступления такого договора в силу [11, с. 211]. Международный договор заключается после переговоров заинтересованными государствами в соответствии с требованиями Венской конвенции о праве международных договоров 1969 г.

Также необходимо проведение референдума по этому вопросу. Самостоятельного отдельного волеизъявления народа недостаточно, учитывая высокий уровень развития избирательных технологий. Следует сделать процент голосов, высказавшихся за передачу территории другому государству, крайне высоким [12]. Поскольку купля-продажа территории как форма цессии в современном международном праве подразумевает под собой приобретение территории, но не населения, одной из гарантий выступает обязательная ратификация договора, лежащего в основе сделки [13, с. 218].

Неизбежно возникнут вопросы, связанные со стоимостью территорий. Поэтому необходимо не допустить, чтобы богатые нации скупали территории у бедных. Покупка территории с 
целью ее дальнейшего развития - замечательная идея, если государство-продавец не в состоянии обеспечить должное развитие инфраструктуры и если экономические и социокультурные интересы населения будут учтены [14].

Также не должно нарушаться право граждан на принадлежность к тому или иному государству. Купля-продажа государственной территории в современном международном праве подразумевает под собой приобретение территории, но не населения. Подобная сделка должна быть инструментом для защиты интересов народа, но не инструментом для его подавления [15]. При передаче территории проживающим на ней лицам должна предоставляться не только возможность оптации гражданства и выбора местожительства в разумные сроки, обычно указанные в договорах, но и возможность оставить себе гражданство бывшего собственника территории [16]. Однако в данных положениях необходимо учесть и интересы государства-покупателя с точки зрения добросовестного проведения сделки. И поскольку цессия в форме продажи государственной территории проводится за согласованную денежную сумму [17], необходимо, чтобы компенсация была равноценной.

Возвращаясь к предложению Д. Трампа о продаже Гренландии, хотелось бы отметить, что территория острова во многом заброшена, характеризуется неразвитой инфраструктурой, из 57 тыс. человек населения 80-90 \% составляют коренные жители - эскимосы. Большая часть территории покрыта льдом. Хотя в 1979 г. Дания предоставила Гренландии широкую автономию, финансово она несамостоятельна. Приблизительно половину доходов бюджета составляют дотации с датской стороны. Также Гренландия значительно зависит от импорта, в том числе потребительских товаров из Дании. Для хозяйственной деятельности освоено около 15 \% площади острова. Основная часть населения занимается натуральным хозяйством и рыбной промышленностью. Также в Гренландии идет небольшая добыча полезных ископаемых.

Несмотря на это, США заинтересованы в Гренландии со стратегической точки зрения. Это крупнейший остров на Земле, а лед в ходе глобального потепления постепенно тает. Остров обладает большими запасами редкоземельных металлов. В 2019 г. между Гренландией и США был подписан Меморандум о взаимопонимании, касающийся сотрудничества в сфере добычи полезных ископаемых, и Совместное заявление, изданное Государственным департаментом США и Министерством минеральных ресурсов и труда Гренландии о совместном гиперспектральном исследовании в Южной Гренландии. Кроме того, интерес США подчеркивает растущее значение Арктики.

Дания отказалась продавать Гренландию, несмотря на предложенные ежегодные субсидии в размере 600 млн долл. В отсутствие более развитого и финансово обеспеченного «собственника» тесное сотрудничество с такими государствами Европы, как Дания и Норвегия, представляется в настоящее время достойной альтернативой покупке Гренландии со стороны США.

На основании проведенного анализа можно сделать вывод, что основные тезисы статьи применимы только к тем государствам, законодательство которых не содержит запрета на отчуждение территории. Введение в 2020 г. в российскую Конституцию принципа незыблемости государственных границ обусловлено наличием в приграничных субъектах РФ территориальных споров с незавершенным договорно-правовым регулированием. Это связано с опасениями относительно возможных территориальных уступок в отношении спорных территорий с Литвой, Украиной, Японией и др. [18, с. 41]. Однако для отдельных государств, например, с «ненадлежащим управлением» (Мьянма, Сирия, Сомали), а также государств без выхода к морю данное предложение представляется выходом для разрешения сложившихся проблем при соблюдении указанных выше гарантий. Поскольку международно-правовой механизм покупки территории одного государства другим не получил своего четкого оформления, при совершении подобных сделок необходимо тесное сотрудничество государств, особенно на спорных территориях.

\section{Ссылки:}

1. Броунли Я. Международное право: в 2 кн. Кн. 1. М., 1977. 538 с.

2. Blocher J., Gulati M. Transferable Sovereignty: Lessons from the History of the Congo Free State // Duke Law Journal. 2020. Vol. 69, no. 6. P. 1219-1273. https://doi.org/10.2139/ssrn.3305851.

3. Клемешев А.П. Проблема эксклавности в условиях глобализации: на примере Калининградской области : дис. ... д-ра полит. наук. М., 2006. 325 с.

4. Лапшина И.Е. Международно-правовое регулирование изменения государственной территории // SCI-ARTICLE.RU : электронный научный журнал. 2019. № 74. URL: https://sci-article.ru/stat.php?i=1569328485 (дата обращения: 25.06.2020).

5. Blocher J., Gulati M. A Market for Sovereign Control // Duke Law Journal. 2017. Vol. 66, no. 4. P. 797-843. https://doi.org/10.2139/ssrn.2557830.

6. Clowney S. Should We Buy Selling Sovereignty? // Duke Law Journal. 2017. Vol. 66. P. 19-36.

7. Ibid. P. 19.

8. Лапшина И.Е. Указ. соч. 
9. Скулаков Р.М. О классификации правовых оснований изменения государственной территории // Юридический вестник ДГУ. 2017. Т. 21, № 1. С. 57-64. https://doi.org/10.21779/2224-0241-2017-21-1-57-64.

10. Чамаров В.Б. Международно-правовые проблемы разграничения государственных территорий и морских пространств: дис. ... канд. юрид. наук. М., 2001. 212 с.

11. Броунли Я. Указ. соч. С. 211

12. Blocher J., Gulati M. A Market for Sovereign Control. P. 842

13. Völkerrecht / herausgegeben von W.G. Vitzthum; bearb. von M. Bothe, E. Klein, M. Schröder, K. Hailbronner, P. Kunig, W. Vitzthum. Berlin, 1997. $687 \mathrm{~s}$

14. Скулаков Р.М. Указ. соч. С. 61.

15. Blocher J., Gulati M. Transferable Sovereignty. P. 1273.

16. Blocher J., Gulati M. A Market for Sovereign Control. P. 842.

17. Чамаров В.Б. Указ. соч. С. 7.

18. Нарутто С.В. К вопросу об изменении государственной границы // NB: Административное право и практика администрирования. 2013. № 12. С. 35-50. https://doi.org/10.7256/2306-9945.2013.12.10698.

Редактор, переводчик: Арсентьева Ирина Ильинична 